\title{
Impact of Different Moodle Course Designs on Students' Performance
}

\author{
http://dx.doi.org/10.3991/ijep.v3iS2.2397 \\ G. R. Alves ${ }^{1}$, M. C. Viegas ${ }^{1}$, M. A. Marques ${ }^{1}$, M. C. Costa-Lobo², A. A. Silva ${ }^{1}$, F. Formanski ${ }^{3}$, J. B. Silva ${ }^{3}$ \\ ${ }^{1}$ Polytechnic of Porto, Porto, Portugal \\ ${ }^{2}$ Universidade Portucalense Infante D. Henrique (UPT), Porto, Portugal \\ ${ }^{3}$ Federal University of Santa Catarina (UFSC), Aranragua, Santa Catarina, Brazil
}

\begin{abstract}
This work describes the impact of different teachers' approaches in using Moodle, for supporting their courses, at the Polytechnic of Porto - School of Engineering. The study covers five different courses, from different degrees and different years, and includes a number of Moodle resources especially supporting laboratory classes. These and other active resources are particularly analyzed in order to evaluate students' adherence to them. One particular course includes a number of remote experiments, made available through VISIR (Virtual Instrument Systems in Reality) and directly accessible through links included in the Moodle course page. The collected data have been correlated with students' classifications in the lab component and in the exam, each one weighting $50 \%$ of their final marks. This analysis benefited from the existence of different teachers' approaches, which resulted in a diversity of Moodlesupported environments. Conclusions point to the existence of a positive correlation factor between the number of Moodle accesses and the final exam grade, although the quality of the resources made available by the teachers seems to be preponderant over its quantity. In addition, different students perspectives were found regarding active resources: while some seem to encourage students to participate (for instance online quiz or online reports), others, more demanding, are unable to stimulate the majority of them.
\end{abstract}

Index Terms-Moodle resources, students' performance, remote laboratories

\section{INTRODUCTION}

In the educational landscape, almost all institutions now have some sort of a Learning Management System (LMS). The use of educational technologies emerges as a great opportunity to improve and complement teaching and learning, by encouraging students to perform different activities that might help them evolve more easily and more according to individual needs. In parallel, the profitability of an experimental distance learning environment involves a multitude of concepts and technologies. In this work, we relate these two features with remote experimentation offered through a LMS platform. The experimental systems, and in particular remote laboratories, have been the subject of efforts to demonstrate their capabilities and advantages for teaching and learning processes in higher education [1].

Since the 90's, several educational institutions have addressed the issue of remote laboratories. Currently, the educational work in the area tries to improve the efficiency and effectiveness in its use, by creating flexible infrastructures that offer features such as authentication, resource reservation, communication tools and access to support materials. Other issues are also considered today as essential for the future of remote laboratories, namely: integration with LMS, flexible interfaces (taking into account usability and accessibility), and infrastructures to facilitate the sharing of experiences. The system integration with an LMS, like Moodle, is explored in this paper.

Moodle [2] is in use at the Polytechnic of Porto School of Engineering (ISEP) since 2006/2007, although few information has been shared about the benefits it brought to the school community or the ways it has been used in support of the many (under and postgraduate) courses offered in-house. An initial study [3] was focused on the general use of this platform by the school community, not including the learning gain achieved by each course.

To address this gap, a comparative study between 4 courses has been conducted $[4,5]$, with the objective of better understanding the usability and the usefulness of different resources designed by teachers in the Moodle course page. In particular it was shown that: i) it doesn't appear to exist a different culture of students enrolled in the usage of Moodle, stated by their degree; ii) there is a small difference between $1^{\text {st }}$ and $2^{\text {nd }}$ year students regarding the search for course information (greater in the first ones) and static resources (greater in the last ones), presumably related to students concerns while being freshman or more adapted to the system; iii) the major differences encountered regarded the kind of activity and not the course itself: all students seek Moodle quizzes to support their learning, but when this did count to their grade (courses 1 and 3), the number of accesses was a little higher, as expected; iv) students respond positively to teachers' effort in scaffolding students learning in a Moodle page by presenting different kinds of activities.

In this paper we present an extension to the research: a fifth course has been included, and it used a new type of resource in Moodle: the remote laboratory VISIR (Virtual Instrument System In Reality). We discuss students' interest and learning patterns while using VISIR as an LMS resource. This addresses one important aspect in Science \& Engineering education: students' experimental competences development through remote labs [6]. 


\section{METHODS}

This work is based on five case-studies (Table I), each one representing Moodle-courses integrations in three different degrees at ISEP. The first four case studies $[4,5]$ focused on: the advantages of presenting a structured Moodle-based course page to students; how the level of Moodle - students interactivity (verifiable through the "Reports” functionally) cross-correlated with the students' final marks; which aspects are especially important to potentiate LMS usage, not only as a repository of information, but as a mean of involving students, using different types of resources. In the fifth case-study, the possibility to access remote labs has been included in the Moodle platform as a new resource. We relied on Moodle analysis tools to gather the corresponding additional information.

The first analysis $[4,5]$ included the Courses 1 to 4 of Table I. One aspect stood-up: students felt as especially useful some "active” resources, such as online questionnaires, online forums and lab reports. In literature, active resources are connoted with less demand from students [7], but in our previous work we found this to be related with several issues, like the type of resource and assessment. We thus introduced another active resource: the remote lab experiments. Its use was not compulsory for students. A particular extra care was taken on the design of the course's Moodle page in order to have a permanent follow-up about remote lab experiments using VISIR. In Course 5, there were 10 lab experiments, 5 of them complemented with similar remote experiments. Students could access the course's Moodle page (Fig.1- $\square$ ) to download the experiment guide, visualize the circuit assembling examples and the remote experiment, by accessing VISIR platform using their institutional access (Fig.1$\square$ and 1- $\square$ ).

The analyzed data includes students' accesses to each Moodle resource and students lab and exam grades. The analysis focuses two domains: Moodle accesses; and correlation between these and students' performance.

One specific aspect deserved our attention: whether or not VISIR requirements - access through a secure connection, «https://», and the need to have Flash player installed - were cause for abandonment when directly accessed through Moodle (Fig.1). We thus will compare the Moodle course reports with the VISIR user tracking system [6].

This work has two objectives: to observe if the pattern encountered in the previous work was consolidated; and to study the influence of the remote lab experiments. By enlarging the type of active resources offered to students, this work intends to contribute to the understanding of the utility of these resources in students learning. The research questions are: (i) Does the type of resources influence the level of engagement of students from different year/degrees? (ii) Does the effort of the head-teacher and the number of available resources correlates with the students' activity in Moodle and results in the final exam? (iii) Does the resource "remote laboratory" have specificities in terms of students' involvement and learning?

\begin{tabular}{|c|c|c|c|c|c|}
\hline & \multicolumn{4}{|c|}{$\begin{array}{l}\text { TABLE I. } \quad \text { CASE STUDIES IDENTIFICATION } \\
\text { [y.: year; s.: semester; Eng.: Engeneering] }\end{array}$} & \multirow[b]{2}{*}{ Course 5} \\
\hline & Course 1 & Course 2 & Course 3 & Course 4 & \\
\hline Degree & Civil Eng. & $\begin{array}{l}\text { Chemistry } \\
\text { Eng. }\end{array}$ & $\begin{array}{l}\text { Electronic } \\
\text { Eng. }\end{array}$ & Electronic Eng. & $\begin{array}{c}\text { Electronic } \\
\text { Eng. }\end{array}$ \\
\hline $\begin{array}{c}\text { Year / } \\
\text { semester }\end{array}$ & $1^{\mathrm{st}} \mathrm{y} \cdot / 2^{\mathrm{nd}} \mathrm{s}$ & $1^{\mathrm{st}} \mathrm{y} \cdot /^{\mathrm{st}} \mathrm{s}$ & $2^{\mathrm{nd}} \mathrm{y} \cdot / 1^{\mathrm{st}} \mathrm{s}$ & $1^{\mathrm{st}} \mathrm{y} \cdot / 2^{\text {nd }} \mathrm{s}$ & $2^{\text {nd }} \mathrm{y} . / 1^{\mathrm{st}} \mathrm{s}$ \\
\hline $\begin{array}{c}\text { Number of } \\
\text { students }\end{array}$ & 492 & 159 & 344 & 617 & 215 \\
\hline $\begin{array}{c}\text { Editor } \\
\text { teachers }\end{array}$ & \begin{tabular}{|c} 
Head-teacher \\
A
\end{tabular} & $\begin{array}{c}\text { Head-teacher } \\
\text { A }\end{array}$ & \begin{tabular}{|c|} 
Head-teacher \\
B
\end{tabular} & $\begin{array}{c}\text { Head-teacher C } \\
+ \text { one teacher }\end{array}$ & $\begin{array}{c}\text { Head- } \\
\text { teacher D + } \\
\text { one teacher } \\
\text { (same as C) }\end{array}$ \\
\hline \begin{tabular}{c||} 
Main \\
objective \\
of Moodle \\
page \\
\end{tabular} & $\begin{array}{c}\text { Repository } \\
\text { and a tool for } \\
\text { learning }\end{array}$ & Repository & $\begin{array}{c}\text { Repository } \\
\text { and a tool for } \\
\text { learning }\end{array}$ & $\begin{array}{c}\text { Repository \& } \\
\text { a tool for } \\
\text { learning }\end{array}$ & $\begin{array}{l}\text { Repository } \\
\& \text { a tool for } \\
\text { learning }\end{array}$ \\
\hline $\begin{array}{l}\text { Course } \\
\text { contents }\end{array}$ & \begin{tabular}{|c|} 
Waves, \\
Electricity, \\
Heat transfer \\
and Optics \\
\end{tabular} & Mechanics & $\begin{array}{l}\text { Waves and } \\
\text { Optics }\end{array}$ & $\begin{array}{l}\text { Electro- } \\
\text { magnetism }\end{array}$ & $\begin{array}{l}\text { Electronics } \\
\text { (intermedi- } \\
\text { ate level) }\end{array}$ \\
\hline $\begin{array}{c}\text { Students' } \\
\text { assessment }\end{array}$ & $\begin{array}{c}10 \% \text { Moodle } \\
\text { assessment } \\
+30 \% \\
\text { laboratory } \\
+60 \% \text { exam }\end{array}$ & $\begin{array}{c}50 \% \\
\text { laboratory } \\
+50 \% \text { exam }\end{array}$ & \begin{tabular}{|c|}
$10 \%$ Moodle \\
quizzes \\
$+35 \%$ \\
laboratory \\
assessment \\
$+55 \%$ exam
\end{tabular} & $\begin{array}{c}50 \% \text { of } \\
\text { continuous } \\
\text { assessment } \\
+50 \% \text { exam }\end{array}$ & $\begin{array}{c}50 \% \text { of } \\
\text { continuous } \\
\text { assessment } \\
+50 \% \\
\text { exam }\end{array}$ \\
\hline
\end{tabular}

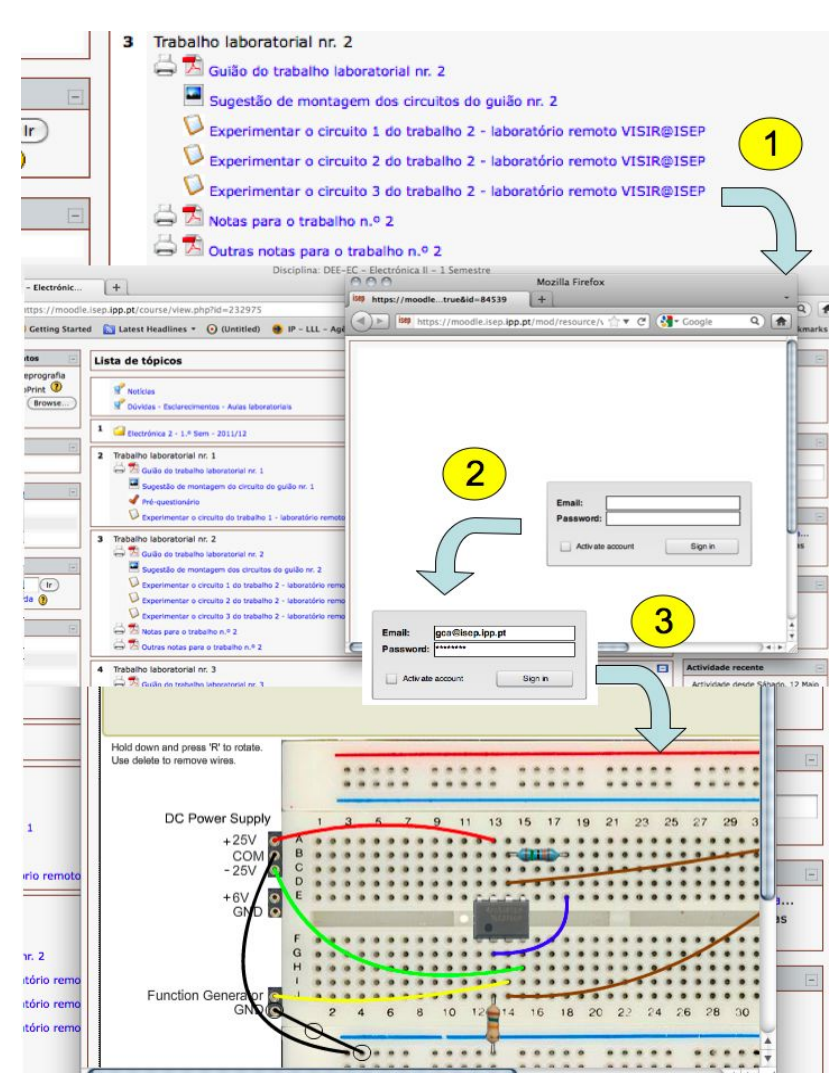

Figure 1. Accessing a remote experiment in VISIR through a direct link in a Moodle course page.

\section{RESULTS AND ANALYSIS}

In this section we present results about Course 5. The analysis has been made as for the others [5], namely about students' accesses characterization and its correlation with their performance. The usage and usefulness of the new active resource is assessed. A comparative analysis between courses is established in order answer the research questions. 


\section{A. Accesses characterization}

In Table II we present an overview of the Moodle resources and accesses per Course. The difference between Participants and Active Participants is that the first subscribed the course but never accessed Moodle. Every access to Moodle (log in) and to any resource (activity) is recorded by Moodle.

The fifth course implementation goes beyond an information repository. It is designed to support teaching and learning along the semester. Moodle's content was arranged in 11 threads: the first is dedicated to news, forums and course materials (under the head-teacher responsibility); and the other 10 were made available along the course in accordance with the lab component corresponding to each main subject (under the responsibility of one of the lab teachers).

As shown in Table III, each topic was designed to have three different resources (R): R1 - lab guides; R2 assembling suggestions; R3 - remote lab experiment in VISIR (when available).

The lab teacher who designed and structured this laboriented Moodle course (one of the five teachers who had lab classes) was also responsible for $20 \%$ of the lab classes. Students could access the remote experiments either by Moodle's link or directly by web access. As shown in Fig. 2, most accesses via Moodle failed: VISIR accesses were much less than Moodle's. This was probably caused by the pop-up window related to secure connections. In the beginning students preferably choose the Moodle's link to the remote experiment and later (due to the described problem) they opted for accessing VISIR directly.

Fig. 3 shows the number of accesses to the resources. $\mathrm{R} 1$ is the most accessed. This is because students had to have the lab guide to do the experiment in class (R1 in Topic 5 is a group of two guides, which led to a higher number of accesses). R2 and R3 were not mandatory. The last had the least accesses.

In Fig. 4 we can see the evolution of students' direct accesses to VISIR (as recorded by its user tracking system) along the semester. A higher density of accesses is observed along October. This is because the first four remote experiments were then made available. The last remote experiment (topic 7) was released at the end of November. This large interval without new proposed experiments can explain the large number of accesses to topic 4 (Fig. 2 and Fig. 3).

TABLE II. OVERVIEW OF MOODLE RESOURCES AND ACCESSES PER COURSE

\begin{tabular}{|l|c|c|c|c|c|}
\cline { 2 - 6 } \multicolumn{1}{c|}{} & Course 1 & Course 2 & Course 3 & Course 4 & Course 5 \\
\hline Participants & $492+6$ & $159+1$ & $344+6$ & $617+6$ & $215+5$ \\
\hline Active Participants & 439 & 155 & 344 & 515 & 180 \\
\hline Moodle resources & 57 & 50 & 44 & 92 & 63 \\
\hline $\begin{array}{l}\text { Dynamic Moodle } \\
\text { resources }\end{array}$ & $\begin{array}{c}2 \text { Quiz + } \\
1 \text { Lab }\end{array}$ & & 6 Quiz & $\begin{array}{c}6 \text { Quiz + 6 } \\
\text { Lab + 22 } \\
\text { Forums }\end{array}$ & $\begin{array}{c}5 \text { Remote } \\
\text { labs + 3 } \\
\text { Forums }\end{array}$ \\
\hline Tot. number of logs & 75920 & 21507 & 72644 & 112943 & 77607 \\
\hline $\begin{array}{l}\text { Tot. activity } \\
\text { accesses }\end{array}$ & 29886 & 9719 & 27502 & 61772 & 57002 \\
\hline $\begin{array}{l}\text { Editor teachers } \\
\text { (number of ac- } \\
\text { cesses) }\end{array}$ & 1706 & 287 & 1661 & 4673 & 778 \\
\hline
\end{tabular}

TABLE III. COURSE 5: MOODLE ACESSES PER RESOURCE AND PARTICIPANT

\begin{tabular}{|c|c|c|c|c|}
\hline Course 5 Activities & $\begin{array}{c}\text { Number } \\
\text { of } \\
\text { resources }\end{array} \mid$ & Accesses & $\begin{array}{c}\text { Average } \\
\text { access per } \\
\text { resource }\end{array}$ & $\begin{array}{c}\text { Average } \\
\text { access per } \\
\text { resource per } \\
\text { participant }\end{array}$ \\
\hline \multicolumn{5}{|l|}{ General information } \\
\hline News & 1 & 150 & 150 & 0.83 \\
\hline Teacher and Students' Forums & 13 & 1106 & 85 & 0.47 \\
\hline Course materials & 14 & 45600 & 3257 & 18.10 \\
\hline \multicolumn{5}{|l|}{ Торіс 1} \\
\hline R1-lab guide 1 & 1 & 727 & 727 & 4.04 \\
\hline R2-lab assembling suggestions & 1 & 296 & 296 & 1.64 \\
\hline Pre-questionnaire & 1 & 526 & 526 & 2.92 \\
\hline R3-Remote lab VISIR@isep & 1 & 376 & 376 & 2.09 \\
\hline \multicolumn{5}{|l|}{ Topic 2} \\
\hline R1-lab guide 2 & 1 & 711 & 711 & 3.95 \\
\hline R2-lab assembling suggestions & 1 & 246 & 246 & 1.37 \\
\hline R3-Remote lab VISIR@isep & 3 & 361 & 120 & 0.67 \\
\hline \multicolumn{5}{|l|}{ Topic 3} \\
\hline R1-lab guide 3 & 1 & 599 & 599 & 3.33 \\
\hline R2-lab assembling suggestions & 1 & 182 & 182 & 1.01 \\
\hline R3-Remote lab VISIR@isep & 1 & 256 & 256 & 1.42 \\
\hline \multicolumn{5}{|l|}{ Topic 4} \\
\hline R1-lab guide 4 & 1 & 686 & 686 & 3.81 \\
\hline R2-lab assembling suggestions & 1 & 148 & 148 & 0.82 \\
\hline R3-Remote lab VISIR@isep & 1 & 208 & 208 & 1.16 \\
\hline \multicolumn{5}{|l|}{ Topic 5} \\
\hline R1-lab guide 5 & 2 & 1216 & 608 & 3.78 \\
\hline R2-lab assembling suggestions & 1 & 211 & 211 & 1.17 \\
\hline \multicolumn{5}{|l|}{ Topic 6} \\
\hline R1-lab guide 6 & 1 & 389 & 389 & 2.16 \\
\hline R2-lab assembling suggestions & 4 & 411 & 103 & 0.57 \\
\hline \multicolumn{5}{|l|}{ Topic 7} \\
\hline R1-lab guide 7 & 1 & 585 & 585 & 3.25 \\
\hline R2-lab assembling suggestions & 1 & 101 & 101 & 0.56 \\
\hline R3-Remote lab VISIR@isep & 1 & 78 & 78 & 0.43 \\
\hline \multicolumn{5}{|l|}{ Topic 8} \\
\hline R1-lab guide 8 & 1 & 547 & 547 & 3.04 \\
\hline R2-lab assembling suggestions & 1 & 110 & 110 & 0.61 \\
\hline \multicolumn{5}{|l|}{ Topic 9} \\
\hline R1-lab guide 9 & 1 & 446 & 446 & 2.48 \\
\hline R2-lab assembling suggestions & 3 & 272 & 91 & 0.50 \\
\hline \multicolumn{5}{|l|}{ Topic 10} \\
\hline R1-lab guide 10 & 1 & 355 & 355 & 1.97 \\
\hline R2-lab assembling suggestions & 2 & 103 & 52 & 0.29 \\
\hline Total & 63 & 57002 & & \\
\hline
\end{tabular}

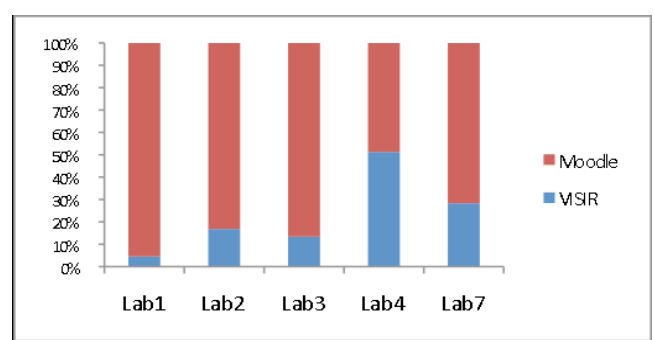

Figure 2. Course 5: direct access to VISIR and accesses via Moodle.

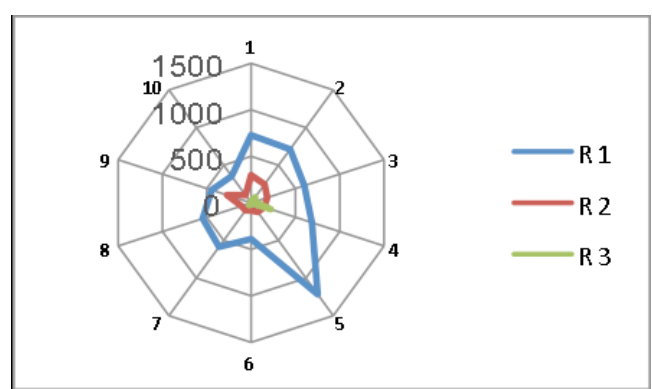

Figure 3. Course 5: Students access distribution per type of resource (R1, R2, R3) for every lab experiments (1-10). 


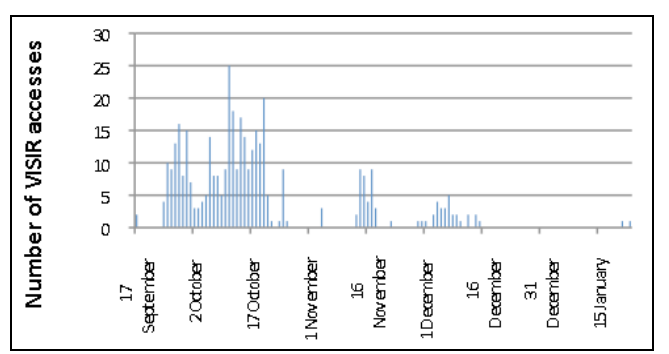

Figure 4. Course 5: VISIR direct accesses along the semester.

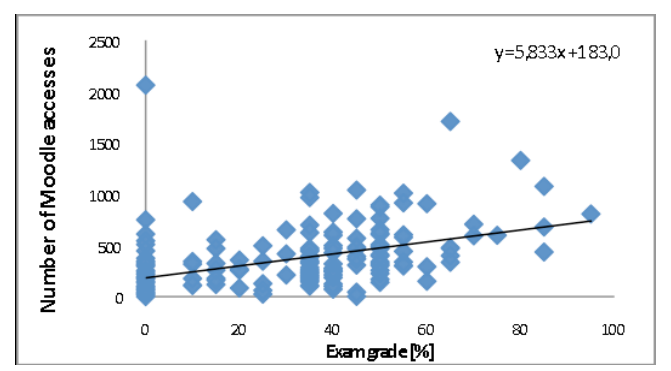

Figure 5. Course 5: correlation between students' accesses and exam results.

\section{B. Correlation between students' accesses and performance}

Following the analysis described in [5], students' accesses to Moodle were compared with exam grades and laboratory grades. In Fig. 5, a small positive correlation can be seen. It is similar to the one in the previously studied Courses.

Since the Moodle course was designed primarily to support the laboratory classes, an analysis relating the lab results was also made. Comparing these Moodle accesses with lab grades an analogous behavior was found. Focusing on VISIR accesses, no relation was depicted showing that students were not able to use it in a productive manner. This might be due to the fact that the majority of students could not overcome the problems that VISIR presented in the beginning of its usage, and therefore saw no point in continuing to use it. In fact, the majority of students had an initial number of tries and then never used it again. Only a small percentage of students actually worked with the 5 remote lab experiments.

\section{Comparative analysis}

Concerning the most accessed type of resources, Course 5 follows a pattern similar to the previous four Courses. It shows a larger preference for general "Course view” action. The resource R3 was not particularly motivating to students, as the average number of accesses per active participant reveals: see Table IV. The same applies to R2. These two resources were the wager to which teacher $\mathrm{C}$ (lab teacher who was responsible for the Moodle lab base structure) committed himself harder, providing different kinds of resources for students. This teacher's effort did not lead to a corresponding students' interest.

Even so, there are statistical significant results in the correlations between the number of Moodle accesses and students' grades in exam and in continuous assessment (lab and other components, along the semester): see Table $\mathrm{V}$. All courses present a more significant value in the
TABLE IV. SUMMARY: AVERAGE ACCESSES PER ACTIVE PARTICIPANT

\begin{tabular}{|c|c|c|c|c|c|}
\hline $\begin{array}{l}\text { Average ac- } \\
\text { cess/participant }\end{array}$ & $\begin{array}{c}\text { Course } \\
1\end{array}$ & $\begin{array}{c}\text { Course } \\
2 \\
\end{array}$ & $\begin{array}{c}\text { Course } \\
3 \\
\end{array}$ & $\begin{array}{c}\text { Course } \\
4\end{array}$ & $\begin{array}{c}\text { Course } \\
5\end{array}$ \\
\hline $\begin{array}{l}\text { Lectures, lab guides } \\
\text { (R1), proposed prob- } \\
\text { lems }\end{array}$ & 1.24 & 1.34 & 2.85 & 1.33 & \multirow[t]{2}{*}{7.57} \\
\hline Course information & 0.94 & 2.44 & 1.41 & 1.71 & \\
\hline $\begin{array}{l}\text { R2- lab assembling } \\
\text { suggestions }\end{array}$ & - & - & - & - & 1.16 \\
\hline $\begin{array}{l}\text { Quizzes contributing to } \\
\text { final grade }\end{array}$ & 4.73 & - & 4.32 & - & - \\
\hline $\begin{array}{l}\text { Quizzes for self- } \\
\text { assessment }\end{array}$ & - & - & - & 3.25 & - \\
\hline On-line report & 5.61 & - & - & 6.95 & - \\
\hline R3- remote lab & - & - & - & - & 1.42 \\
\hline
\end{tabular}

TABLE V. STUDENTS’ ACESSES AND GRADES: PEARSONS’ ANALYSIS

\begin{tabular}{c||c|c|c|c|c|}
\hline $\begin{array}{c}\text { Correlations of } \\
\text { students' number of } \\
\text { Moodle accesses with: }\end{array}$ & $\begin{array}{c}\text { Course } \\
\mathbf{1}\end{array}$ & $\begin{array}{c}\text { Course } \\
\mathbf{2}\end{array}$ & $\begin{array}{c}\text { Course } \\
\mathbf{3}\end{array}$ & $\begin{array}{c}\text { Course } \\
\mathbf{4}\end{array}$ & $\begin{array}{c}\text { Course } \\
\mathbf{5}\end{array}$ \\
\hline - Continuous assessment & $0.410^{* *}$ & $0.210^{*}$ & $0.324^{* *}$ & $0.453^{* *}$ & $0.454^{* *}$ \\
\hline Exam & $0.259^{* *}$ & $0.200^{*}$ & $0.166^{*}$ & $0.380^{* *}$ & 0.138 \\
\hline
\end{tabular}
**Correlation is significant at the 0.01 level (2-tailed).
* Correlation is significant at the 0.05 level (2-tailed).

continuous assessment than in the exam, presumably because the tasks proposed in the platform were more related to students' assessment during the semester. Courses 1, 4 and 5 - the ones with more available dynamic resources (forums, quizzes, online reports or remote labs - are the ones with higher correlations, in continuous assessment.

\section{CONCLUSIONS}

Summarizing data from all cases, it becomes clear what students searched for in the LMS resources. Students prefer static materials (such as lectures, lab guides and proposed problems). This was similar in all year/degrees, and is consonant with results obtained in the previous analysis [5]: for quizzes and laboratory online reports, students respond well to teachers' solicitations. Nevertheless, this preference was more pronounced in Course 5, the case where all the remaining structure of Moodle page relied on lab accompaniment.

As stated above, the effort to implement VISIR experiments via Moodle did not lead to a corresponding students' interest. Remote lab experiments, being a demanding dynamic resource (and not compulsory, in this particular case), outcomes in a low students' attendance [7] and does not correlate with their final grades.

This is consistent with our previous work [4, 5]: the number of students who find usefulness in other dynamic resources, like forum discussions or online reports, is residual.

We thus depict two trends: the usefulness of static resources is readily comprehensible to students; students tend to avoid tasks that seem too demanding or time consuming. Other authors refer the relevance of the last tendency, e.g. [7], which reports that the frequency of use of an LMS functionality decreases as it becomes more 'engaging'.

It should be stressed that the lab teacher who was responsible for the Moodle lab base structure was not the 
head-teacher; neither the only teacher of lab classes. Besides, the teachers who participated in this study were not obliged to use VISIR, and some of them did not use it for themselves. Presumably, these teachers did not motivate students to do it. These factors might have also influenced our results.

The tasks to be made in VISIR were not compulsory for students and, apparently, they did not comprehend their long-term learning benefits [8]. This indicates that the teacher mediation should be refined, as it is crucial to engage students in a fruitful way, particularly in this kind of activities [9, 10]. Another indicator about the need of teacher mediation refinement is the lack of correlation between students' usage of VISIR and their lab grades: this is most likely due to problems which students were not able to overcome on their own. As another hint to further research in this field, we stress that the fact that a resource has little use does not necessarily mean that the resource is strictly not useful: it might mean that it helps only a small percentage of students.

As an overall summary, we emphasize that our results show statistically significant correlations between the variety and quality of Moodle resources and students' results. A larger variety of activities enables to spread the platform, reaching different types of learning. This ultimately helps to potentiate students' interest and learning development.

\section{REFERENCES}

[1] E. D. Lindsay, and M. C. Good, "Effects of laboratory access modes upon learning outcomes," IEEE Transactions on Education, vol.48, no.4, pp. 619- 631, Nov. 2005 http://dx.doi.org/10.1109/TE.2005.852591

[2] http://moodle.org

[3] B. P. Marques, J. E. Villate, and C. V. Carvalho, Technology Acceptance on Higher Education: the case of an Engineer's School. ICERI2010, International Conference of Education Research and Innovation, 15-17 November, Madrid, Spain, CD Proceedings, ISBN: 978-84-614-2439-9, pp. 5094-5102, 2010.

[4] G. R. Alves, M. A. Marques, M. C. Viegas, and M. C. Costa Lobo, "Structuring and Moodleing a Course: Case studies at the Polytechnic of Porto - School of Engineering”, 3rd IEEE Engineering Education Conference (EDUCON'12) Marrakesh, Morocco, 17-20 April 2012.

[5] C. Viegas, A. Marques, G. Alves and C. Costa-Lobo, "Engaging Students by Moodleing a Course? Case Studies at the Polythecnic of Porto - School of Engineering”, International Journal of
Engineering Pedagogy (iJEP), North America, 2 (3), June 2012 pp. 40-46. http://dx.doi.org/10.3991/ijep.v2i3.2154

[6] G. R. Alves, M. A. Marques, C. Viegas, M. C. Costa Lobo, R. G. Barral, R. J. Couto, F. L. Jacob, C. A. Ramos, G. M. Vilão, D. S. Covita, Joaquim Alves, P. S. Guimarães, and I. Gustavsson, "Using VISIR in a large undergraduate course: Preliminary assessment results”, 2nd IEEE Engineering Education Conference (EDUCON’11) Amman, Jordania, 4-6 April 2011.

[7] A. Carvalho, N. Areal, and J. Silva, "Students' Perception of Blackboard and Moodle in a Portuguese University", British Journal of Education Technology, 42 (5), pp. 824-841, 2011. http://dx.doi.org/10.1111/j.1467-8535.2010.01097.x

[8] J. Biggs, What the Student Does: teaching for enhanced learning, Higher Education Research \& Development, 18(1), pp 57-75, 1999. http://dx.doi.org/10.1080/0729436990180105

[9] J. B. Lopes, J. P. Cravino, and A. A. Silva, “A Model for Effective Teaching in Science and Technology (Metilost). New York: Nova Science Publishers, Inc, 2010.

[10] M. A. Bochicchio and A. Longo, "Learning Objects and Online Labs: the MicroNet Experience", Proceedings of the Remote Engineering \& Virtual Instrumentation (REV) conference, pp. 308-314, Bilbao, Spain, 4-6 July 2012.

\section{AUTHORS}

G. R. Alves, M. C. Viegas, and M. A. Marques are with the Polytechnic of Porto - School of Engineering, Porto, Portugal (e-mail: \{gca,mcm,mmr\}@ isep.ipp.pt).

M. C. Costa-Lobo was with the Polytechnic of Porto - School of Engineering, Porto, Portugal. She is now with the Department of Educational Sciences and Heritage, University Portucalence, Porto, Portugal, (e-mail: ccostalobo@upt.pt).

A. A. Silva is with the Polytechnic of Porto - School of Education, Porto, Portugal (e-mail: aasilva@ ese.ipp.pt).

F. Formanski was with the Polytechnic of Porto School of Engineering, Porto, Portugal, on leave from the the Federal University of Santa Catarina, Aranragua, SC, Brazil, (e-mail: francielinformanski@gmail.com)

J. B. Silva is with the Federal University of Santa Catarina, Aranragua, SC, Brazil, (e-mail: juarez.silva@ararangua.ufsc.br)

This article is an extended and modified version of a paper presented at the International Conference on Engineering Pedagogy (IGIP2012), held 26 - 28 September 2012, in Villach, Austria. Received 30 November 2012. Published as resubmitted by the authors 27 February 2013. 